\title{
Evaluation of Ethiopian Bread Wheat Cultivars for Slow Rusting Resistance to Yellow Rust (Puccinia striiformis f.s Tritici)
}

\author{
Alemu Ayele Zerihun \\ Kulumsa Agricultural Research Center, Ethiopian Institute of Agricultural Research (EIAR), Assela, Ethiopia \\ Email address: \\ alemuayele81@gmail.com \\ To cite this article: \\ Alemu Ayele Zerihun. Evaluation of Ethiopian Bread Wheat Cultivars for Slow Rusting Resistance to Yellow Rust (Puccinia striiformis f.s \\ Tritici). American Journal of Life Sciences. Vol. 9, No. 4, 2021, pp. 60-66. doi: 10.11648/j.ajls.20210904.11
}

Received: May 18, 2021; Accepted: July 5, 2021; Published: July 13, 2021

\begin{abstract}
Wheat stripe rust (Puccinia striiformis f.s. tritici) is the greatest vicious rust disease in wheat-growing areas of Ethiopia. The cultivating of cultivars with polygenic gene resistance is the most efficient way of monitoring the disease. Field experiments were carried out at Kulumsa Agricultural Research Center main station and, Meraro and Bekoji substations of Ethiopia during 2019 to 2020 main cropping seasons to disclose variability for field based adult plant resistance to yellow rust among 25 newly developed bread wheat cultivars advanced in Ethiopia. Features used as criteria to identify adult plant resistance comprised response of wheat cultivars to yellow rust, Coefficient of infection (CI), relative final rust severity (FRS) and area under disease progress curve (rAUDPC) were found to be reliable to evaluate slow rusting in the cultivars. The outcomes shown that wheat cultivar only Balcha had low disease severity $(<30 \%)$ with MRMS reaction, lower rAUDPC values $(>30 \%)$ and $\mathrm{CI}(<$ 20) and were recognized to have good level of adult plant resistance while eighty eight percent of the tested cultivars exhibited susceptible and grouped under low slow rusting resistance with high disease pressure over all three locations. Cultivars Dashen, Daka, Wane and Sanate had moderate values for slow rusting parameters and were recognized as having moderate level of slow rusting. The slow rusting cultivars identified from the present work can be used for extra management in wheat development programs.
\end{abstract}

Keywords: Yellow Rust, Bread Wheat, Cultivar, Severity, Low Rusting

\section{Introduction}

Wheat yellow rust, caused by Puccinia striiformis is one of the most prevalent and damaging diseases of wheat globally [1], particularly in cool climates, present in almost all the wheat growing areas of the world and a formidable threat to global wheat production [2-4]. It is the major bottleneck in major wheat producing area of Ethiopia especially Arsi and Bale regions are the known hotspot areas for the epidemics of wheat stripe rust $[5,6]$. The main reasons for periodic outbreaks of yellow rust disease in Ethiopia is the scarce information on the genetic variation of host-pathogen interactions and unreliability of current sources of resistance to the prevailing race population [7].

Wheat yellow rust is the most prevalent type of rust, which causes yield losses up to 91.5 to $96.7 \%$ on susceptible cultivars and 48.7 to $57.5 \%$ on moderately susceptible cultivars [8]. The best alternative to reduce losses from such a disease would be to use resistant cultivars. Cultivation of resistant varieties of wheat against stripe rust is effective, feasible and environmentally friendly method of disease control [9]. However, cultivars with race-specific genes usually remain effective for only a few years because the pathogen changes to virulent on individual resistant genes and some plants are also resistant to stripe rust at the adult plant stage (boot stage); such plants have high temperature adult plant (HTAP) resistance.

Bread wheat cultivars relying on single gene resistance having with major gene effect often has low effectiveness to yellow rust disease resistance and breaks its resistance within a few years by forming instability of selection for aggressive yellow rust races $[10,11]$. Because of instability of resistance in cultivars that have only a single major gene effect for resistance, current breeding programs have concentrated on 
rising cultivars with slow rusting. Slow rusting resistance is a type of resistance that is characterized by a reduced rate of epidemic development despite compatible host pathogen interaction $[12,13]$. It is polygenic and effective against a broad range of yellow rust races [14-16]. Slow rusting resistance is described by a slow epidemic build up regardless of a high infection type representing a compatible host-pathogen relationship [17, 13].

Even though numerous findings have been supported out to evaluate yellow rust resistance in different wheat cultivars in Ethiopia, many of them were based on vertical resistance. Thus, the present study was planned to evaluate the levels of slow rusting resistance in some currently cultivated commercial bread wheat cultivars to yellow rust under field conditions.

\section{Materials and Methods}

To evaluate 25 released bread wheat cultivars (Table 1) for their slow rusting resistance to yellow rust. Field experiments were conducted during 2019 to 2020 main cropping season (June to November) at Kulumsa Agricultural Center main station, and Bekoji and Meraro sub stations. Wheat cultivar Morocco which is universal susceptible variety considered to lack resistance genes to the yellow rust pathogen was used as a comparative control in the experiments. The experiments were laid out in randomized complete block design (RCBD) with four replications. Each plot consisted of two rows with a size of $1 \mathrm{~m} \times 40 \mathrm{~cm}$ and a spacing of $1 \mathrm{~m}$ between blocks and 0.2 $\mathrm{m}$ between plots. To ensure uniform spread of inoculum and for sufficient disease development during the trial periods susceptible wheat cultivar Morocco was planted a week earlier around the experimental areas. Artificial inoculation was not carried out due to high yellow rust disease pressure and highly hot spotted experimental sites naturally. The recommended fertilizer application, insect and weed control methods were undertaken as per recommendations.

Table 1. Description of the wheat cultivars used for evaluation of slow rusting resistance.

\begin{tabular}{|c|c|c|c|c|c|c|c|}
\hline S/NO & Cultivars & Year of release & Source & S/NO & Cultivars & Year of release & Source \\
\hline 1 & Digalu & 2004 & KARC/EIAR & 14 & Danda'a & 2010 & KARC/EIAR \\
\hline 2 & Kubsa & 1995 & KARC/EIAR & 15 & Lemmu & 2016 & KARC/EIAR \\
\hline 3 & PBW343 & 1995 & KARC/EIAR & 16 & Alidoro & 2007 & KARC/EIAR \\
\hline 4 & Dashen & 1984 & Adet & 17 & Huluka & 2012 & KARC/EIAR \\
\hline 5 & Lakech & 1967 & KARC/EIAR & 18 & Hoggana & 2012 & KARC/EIAR \\
\hline 6 & Sanate & 2014 & KARC/EIAR & 19 & Madawalabu & 2000 & Sinana/OARI \\
\hline 7 & Isreal & - & Adapted & 20 & Hidasie & 2012 & KARC/EIAR \\
\hline 8 & Enkoy & 1974 & Adapted & 21 & Kingbird & 2015 & KARC/EIAR \\
\hline 9 & Pavon 76 & 1982 & KARC/EIAR & 22 & Wane & 2016 & KARC/EIAR \\
\hline 10 & Shorima & 2011 & KARC/EIAR & 23 & DAKA & 2018 & KARC/EIAR \\
\hline 11 & Galama & 1995 & KARC/EIAR & 24 & Balcha & 2018 & KARC/EIAR \\
\hline 12 & Kakaba & 1995 & KARC/EIAR & 25 & Morocco & Susce.c & KARC/EIAR \\
\hline 13 & Ogolcho & 2013 & KARC/EIAR & & & & \\
\hline
\end{tabular}

KARC, Kulumsa Agricultural Research Center, EIAREthiopian Institute of Agricultural Research, OARI- Oromia Agricultural Research Institute.

\subsection{Disease Scoring}

Disease Scoring was made three times at Kulumsa and Bekoji, and four times at Meraro experimental stations at fourteen days interval, starting when susceptible spreader rows reached $20 \%$ severity according to the Modified Cobb Scale [18].

\subsection{Final Rust Severity (FRS)}

Disease severity was assessed by estimating the approximate percentage of leaf area affected using modified Cobb scale on all tillers of plot based entries of two rows. Disease severity was taken at fourteen days interval starting when yellow rust levels on Morocco reached 20\% severity. The host plant response to infection was scored according to [19]. Final rust severity (FRS) was used to classify wheat genotypes into different group such as 1-30 percent as moderately resistant, 31-50 percent as moderately susceptible and 51-90 percent as susceptible.

\subsection{Coefficient of Infection (CI)}

Coefficient of infection was calculated by multiplying the percentage severity and the constant value assigned to each reaction type [20]. The constant values were considered as no disease $=0$, Resistant $(\mathrm{R})=0.2$, Moderately Resistant $(\mathrm{MR})$ $=0.4$, Moderately Resistant to Moderately Susceptible $(\mathrm{MRMS})=0.6$, Moderately Susceptible (MS) $=0.8$, Moderately Susceptible to Susceptible (MSS) $=0.9$, Susceptible $(\mathrm{S})=1$

\subsection{AUDPC and rAUDPC Value}

Area under disease progress curve: calculated using the CI values from the original rust severity data by using the following formula as suggested by [21].

AUDPC (Area under Disease Progress Curve) and rAUDPC (Relative Area under Disease Progress Curve) values were calculated as [22].

$$
A U D P C=\frac{N 1(X 1+X 2}{2}+\frac{N 2(X 2+X 3)}{2}+\frac{N 3(X 3+X 4)}{2}
$$

Where, $\mathrm{X} 1, \mathrm{X} 2, \mathrm{X} 3$ and $\mathrm{X} 4$ are rust intensities recorded on first, second, third and fourth recording date and $\mathrm{N} 1$ is 
interval day between $\mathrm{X} 1$ and $\mathrm{X} 2 \mathrm{~N} 2$ is interval day between $\mathrm{X} 2$ and $\mathrm{X} 3, \mathrm{~N} 3$ is interval day between $\mathrm{X} 3$ and $\mathrm{X} 4$

$$
r A U D P C=\left(\frac{\text { line } A U D P C}{\text { Susceptible AUDPC }}\right) 100
$$

\section{Results and Discussion}

\subsection{Final Rust Severity}

There is wide difference in the severities of wheat stripe rust ranging from trace to $90 \%$ at all location during the 2019 and 2020 cropping seasons at the Kulumsa Agricultural research center main stations and Meraro and Bekoji substations. The final rust severities and field disease infection of cultivars are presented in the table 2. The tested wheat cultivars based on final rust severities were grouped into three groups slow rusting resistance that are high, intermediate and low levels of adult plant resistance with ranges of 1-30, 31-50 and 51-100\% final rust severities values respectively.

At Bekoji experimental station only three cultivars showed disease severities 0 to $30 \%$, three cultivars displayed moderately susceptible $31-50$ and twenty cultivars, grouped to low adult plant resistance having high disease (51-100\%) severities which were highly susceptible cultivars during 2019. At Meraro five wheat cultivars showed up to $30 \%$ disease severities, of which DAKA and Sanate showed MS, Dashen displayed MR, Wane showed MRMS and Pavon 76 showed S type disease reaction. On the other hand four cultivars namely Galema, Alidoro, Hoggana and Wane remained on the second group exhibiting final rust severities
31 to $50 \%$ and sixteen cultivars showed low plant resistance with high disease severities exhibiting $51-100 \%$ with $\mathrm{S}$ type disease reaction, but at Kulumsa three cultivars namely Balcha with MR disease reaction, Dashen and Sanate with nil and MS disease reaction exhibited nine and thirteen cultivars represented intermediate and low adult plant resistance respectively in 2019. Cultivars Sanate, Dashen and Balcha showed moderately resistance at Meraro and moderately susceptible at Bekoji and Kulumsa during 2019 growing season.

At kulumsa five, nine and eleven cultivars showed High (0-30\%), intermediate (31-50\%) and low (51-100\%) slow rusting in disease severity during 2020 cropping season respectively. However the heavy disease pressure at Meraro only one cultivar Balcha displayed high adult plant resistance with MRMS type of disease reaction, two namely DAKA and Wane exhibited $31-50 \%$ of disease severities having MS disease reaction and twenty two cultivars exhibiting 88 percent of the planted materials grouped under low plant resistance having high disease severities and $\mathrm{S}$ type disease reactions severities during 2020 growing season respectively. Cultivar like Sanate showed immune disease response at kulumsa could be as result of response of hypersensitive resistance often breaks down pathogen of new race development. As suggested by [23] available resistance genes like materials overcome yellow rust virulence in the field and low disease severities led to the compatible host plant reaction. Many researchers like [24-28] marked final yellow rust severity to study adult plant resistance or slow rusting characters of wheat cultivars.

Table 2. Stripe rust severities and response of commercial cultivars at Kulumsa, Meraro and Bekoji in 2019 cropping season.

\begin{tabular}{|c|c|c|c|c|c|c|c|c|c|c|}
\hline \multirow{2}{*}{ S/NO } & \multirow{2}{*}{ Cultivars/Varieties } & \multicolumn{3}{|c|}{ Kulumsa } & \multicolumn{3}{|c|}{ Meraro } & \multicolumn{3}{|c|}{ Bekoji } \\
\hline & & FRS & Drxn & CI & FRS & Drxn & CI & FRS & Drxn & CI \\
\hline 1 & Digalu & 70 & $\mathrm{~S}$ & 70 & 90 & $\mathrm{~S}$ & 90 & 80 & $\mathrm{~S}$ & 80 \\
\hline 2 & Kubsa & 80 & $\mathrm{~S}$ & 80 & 80 & $\mathrm{~S}$ & 80 & 50 & $\mathrm{~S}$ & 50 \\
\hline 3 & PBW343 & 80 & $\mathrm{~S}$ & 80 & 60 & $\mathrm{~S}$ & 60 & 60 & $\mathrm{~S}$ & 60 \\
\hline 4 & Dashen & 10 & MS & 8 & 15 & MSMR & 9 & 5 & MS & 4 \\
\hline 5 & Laketch & 80 & $\mathrm{~S}$ & 80 & 90 & $\mathrm{~S}$ & 90 & 50 & $\mathrm{~S}$ & 50 \\
\hline 6 & Sanate & 0 & 0 & 0 & Trace & MS & 3.6 & 10 & MS & 8 \\
\hline 7 & Isreal & 80 & $\mathrm{~S}$ & 80 & 90 & $\mathrm{~S}$ & 90 & 40 & $\mathrm{~S}$ & 40 \\
\hline 8 & Enkoy & 70 & $\mathrm{~S}$ & 70 & 70 & $\mathrm{~S}$ & 70 & 40 & $\mathrm{~S}$ & 40 \\
\hline 9 & Pavon 76 & 40 & $\mathrm{~S}$ & 40 & 30 & $\mathrm{~S}$ & 30 & 30 & $\mathrm{~S}$ & 30 \\
\hline 10 & Shorima & 40 & $\mathrm{~S}$ & 40 & 60 & $\mathrm{~S}$ & 60 & 40 & $\mathrm{~S}$ & 40 \\
\hline 11 & Galema & 40 & $\mathrm{~S}$ & 40 & 40 & $\mathrm{~S}$ & 40 & 30 & $\mathrm{~S}$ & 30 \\
\hline 12 & Kakaba & 60 & $\mathrm{~S}$ & 60 & 70 & $\mathrm{~S}$ & 70 & 40 & $\mathrm{~S}$ & 40 \\
\hline 13 & Ogolcho & 40 & $\mathrm{~S}$ & 40 & 70 & $\mathrm{~S}$ & 70 & 10 & $\mathrm{~S}$ & 10 \\
\hline 14 & Danda'a & 60 & $\mathrm{~S}$ & 60 & 60 & $\mathrm{~S}$ & 60 & 40 & $\mathrm{~S}$ & 40 \\
\hline 15 & Lemmu & 60 & $\mathrm{~S}$ & 60 & 70 & $\mathrm{~S}$ & 70 & 50 & $\mathrm{~S}$ & 50 \\
\hline 16 & Alidoro & 40 & $\mathrm{~S}$ & 40 & 50 & $\mathrm{~S}$ & 50 & 50 & $\mathrm{~S}$ & 50 \\
\hline 17 & Huluka & 40 & $\mathrm{~S}$ & 40 & 70 & $\mathrm{~S}$ & 70 & 70 & $\mathrm{~S}$ & 70 \\
\hline 18 & Hoggana & 60 & $\mathrm{~S}$ & 60 & 50 & $\mathrm{~S}$ & 50 & 50 & $\mathrm{~S}$ & 50 \\
\hline 19 & Madda Walabu & 80 & $\mathrm{~S}$ & 80 & 80 & $\mathrm{~S}$ & 80 & 30 & $\mathrm{~S}$ & 30 \\
\hline 20 & Hidassie & 40 & $\mathrm{~S}$ & 40 & 60 & $\mathrm{~S}$ & 60 & 60 & $\mathrm{~S}$ & 60 \\
\hline 21 & Kingbird & 70 & $\mathrm{~S}$ & 70 & 70 & $\mathrm{~S}$ & 70 & 40 & $\mathrm{~S}$ & 40 \\
\hline 22 & Wane & 40 & $\mathrm{~S}$ & 40 & 50 & $\mathrm{~S}$ & 50 & 20 & MSS & 18 \\
\hline 23 & Daka & 40 & $\mathrm{~S}$ & 40 & 30 & MS & 27 & 30 & $\mathrm{~S}$ & 30 \\
\hline 24 & Balcha & Trace & MR & 1.6 & 5 & MRMS & 3 & 5 & 10MRMS & 6 \\
\hline 25 & Morocco & 90 & $\mathrm{~S}$ & 90 & 90 & $\mathrm{~S}$ & 90 & 80 & $\mathrm{~S}$ & 80 \\
\hline
\end{tabular}

FRS, final rust severity; CI, Coefficient of Infection; Drxn= disease reaction; MRMS; moderately resistant to moderately susceptible; MS, moderately susceptible, MSS, moderately susceptible to susceptible, S, susceptible. 
Table 3. Stripe rust severities and response of commercial cultivars at Kulumsa, Meraro and Bekoji in 2020 cropping season.

\begin{tabular}{|c|c|c|c|c|c|c|c|c|c|c|}
\hline \multirow{2}{*}{ S/NO } & \multirow{2}{*}{ Cultivars/Varieties } & \multicolumn{3}{|c|}{ Kulumsa } & \multicolumn{3}{|c|}{ Meraro } & \multicolumn{3}{|c|}{ Bekoji } \\
\hline & & FRS & Drxn & CI & FRS & Drxn & CI & FRS & Drxn & CI \\
\hline 1 & Digalu & 90 & $\mathrm{~S}$ & 90 & 90 & $\mathrm{~S}$ & 90 & 90 & $\mathrm{~S}$ & 90 \\
\hline 2 & Kubsa & 90 & $\mathrm{~S}$ & 90 & 90 & $\mathrm{~S}$ & 90 & 90 & $\mathrm{~S}$ & 90 \\
\hline 3 & PBW343 & 70 & $\mathrm{~S}$ & 70 & 90 & $\mathrm{~S}$ & 90 & 90 & $\mathrm{~S}$ & 90 \\
\hline 4 & Dashen & 60 & $\mathrm{~S}$ & 60 & 80 & $\mathrm{~S}$ & 80 & 70 & $\mathrm{~S}$ & 70 \\
\hline 5 & Laketch & 80 & $\mathrm{~S}$ & 80 & 90 & $\mathrm{~S}$ & 90 & 90 & $\mathrm{~S}$ & 90 \\
\hline 6 & Sanate & 50 & $\mathrm{~S}$ & 50 & 70 & $\mathrm{~S}$ & 70 & 70 & $\mathrm{~S}$ & 70 \\
\hline 7 & Isreal & 60 & $\mathrm{~S}$ & 60 & 90 & $\mathrm{~S}$ & 90 & 90 & $\mathrm{~S}$ & 90 \\
\hline 8 & Enkoy & 50 & $\mathrm{~S}$ & 50 & 80 & $\mathrm{~S}$ & 80 & 60 & $\mathrm{~S}$ & 60 \\
\hline 9 & Pavon 76 & 40 & $\mathrm{~S}$ & 40 & 80 & $\mathrm{~S}$ & 80 & 60 & $\mathrm{~S}$ & 60 \\
\hline 10 & Shorima & 50 & $\mathrm{~S}$ & 50 & 80 & $\mathrm{~S}$ & 80 & 60 & $\mathrm{~S}$ & 60 \\
\hline 11 & Galema & 40 & $\mathrm{~S}$ & 40 & 70 & $\mathrm{~S}$ & 70 & 70 & $\mathrm{~S}$ & 70 \\
\hline 12 & Kakaba & 60 & $\mathrm{~S}$ & 60 & 90 & $\mathrm{~S}$ & 90 & 60 & $\mathrm{~S}$ & 60 \\
\hline 13 & Ogolcho & 90 & $\mathrm{~S}$ & 90 & 90 & $\mathrm{~S}$ & 90 & 90 & $\mathrm{~S}$ & 90 \\
\hline 14 & Danda'a & 30 & $\mathrm{~S}$ & 30 & 80 & $\mathrm{~S}$ & 80 & 70 & $\mathrm{~S}$ & 70 \\
\hline 15 & Lemmu & 50 & $\mathrm{~S}$ & 50 & 80 & $\mathrm{~S}$ & 80 & 30 & $\mathrm{~S}$ & 30 \\
\hline 16 & Alidoro & 30 & $\mathrm{~S}$ & 30 & 60 & $\mathrm{~S}$ & 60 & 40 & $\mathrm{~S}$ & 40 \\
\hline 17 & Huluka & 50 & $\mathrm{~S}$ & 50 & 70 & $\mathrm{~S}$ & 70 & 80 & $\mathrm{~S}$ & 80 \\
\hline 18 & Hoggana & 40 & $\mathrm{~S}$ & 40 & 70 & $\mathrm{~S}$ & 70 & 80 & $\mathrm{~S}$ & 80 \\
\hline 19 & Madda Walabu & 70 & $\mathrm{~S}$ & 70 & 70 & $\mathrm{~S}$ & 70 & 80 & $\mathrm{~S}$ & 80 \\
\hline 20 & Hidassie & 60 & $\mathrm{~S}$ & 60 & 60 & $\mathrm{~S}$ & 60 & 50 & $\mathrm{~S}$ & 50 \\
\hline 21 & Kingbird & 40 & $\mathrm{~S}$ & 40 & 90 & $\mathrm{~S}$ & 90 & 70 & $\mathrm{~S}$ & 70 \\
\hline 22 & Wane & 30 & MRMS & 18 & 50 & MSS & 40 & 25 & MRMS & 15 \\
\hline 23 & Daka & 10 & MRMS & 6 & 40 & MSMR & 24 & 40 & MRMS & 24 \\
\hline 24 & Balcha & 5 & MRMS & 3 & 25 & MRMS & 15 & 20 & MRMS & 12 \\
\hline 25 & Morocco & 90 & $\mathrm{~S}$ & 90 & 90 & $\mathrm{~S}$ & 90 & 90 & $\mathrm{~S}$ & 90 \\
\hline
\end{tabular}

FRS, final rust severity; CI, Coefficient of Infection; Drxn= disease reaction; MRMS; moderately resistant to moderately susceptible; MS, moderately susceptible, MSS, moderately susceptible to susceptible, S, susceptible.

Table 4. Stripe rust AUDPC and rAUDPC values of commercial cultivars at Kulumsa, Meraro and Bekoji in 2019 cropping season.

\begin{tabular}{|c|c|c|c|c|c|c|c|}
\hline \multirow{2}{*}{ S/NO } & \multirow{2}{*}{ Cultivars } & \multicolumn{2}{|l|}{ Kulumsa } & \multicolumn{2}{|l|}{ Meraro } & \multicolumn{2}{|l|}{ Bekoji } \\
\hline & & AUDPC & rAUDPC & AUDPC & rAUDPC & AUDPC & rAUDPC \\
\hline 1 & Digalu & 1237.5 & 76.39 & 2980 & 80.76 & 950 & 62.5 \\
\hline 2 & Kubsa & 1305 & 80.56 & 3160 & 85.64 & 1140 & 75 \\
\hline 3 & PBW343 & 1005 & 62.04 & 2460 & 66.67 & 1140 & 75 \\
\hline 4 & Dashen & 82 & 5.06 & 615 & 16.67 & 142.5 & 9.38 \\
\hline 5 & Lakech & 1305 & 80.56 & 3290 & 89.16 & 1140 & 75 \\
\hline 6 & Sanate & 82 & 5.06 & 140 & 3.79 & 0 & 0 \\
\hline 7 & Isreal & 717.5 & 44.29 & 3200 & 86.72 & 1140 & 75 \\
\hline 8 & Enkoy & 710 & 43.83 & 2630 & 71.27 & 760 & 50 \\
\hline 9 & Pavon 76 & 355 & 21.91 & 1320 & 35.77 & 617.5 & 40.63 \\
\hline 10 & Shorima & 227 & 14.01 & 2060 & 55.83 & 475 & 31.25 \\
\hline 11 & Galama & 317.5 & 19.6 & 1580 & 42.82 & 475 & 31.25 \\
\hline 12 & Kakaba & 717.5 & 44.29 & 2590 & 70.19 & 760 & 50 \\
\hline 13 & Ogolcho & 205 & 12.65 & 2720 & 73.71 & 475 & 31.25 \\
\hline 14 & Danda'a & 302 & 18.64 & 2150 & 58.27 & 712.5 & 46.88 \\
\hline 15 & Lemmu & 432 & 26.67 & 2500 & 67.75 & 760 & 50 \\
\hline 16 & Alidoro & 224 & 13.83 & 1670 & 45.26 & 427.5 & 28.13 \\
\hline 17 & Huluka & 162 & 10 & 2190 & 59.35 & 475 & 31.25 \\
\hline 18 & Hogana & 315 & 19.44 & 1120 & 30.35 & 630 & 41.47 \\
\hline 19 & Madawalabu & 102.5 & 6.33 & 1230 & 33.33 & 475 & 31.25 \\
\hline 20 & Hidasie & 307.5 & 18.98 & 2460 & 66.67 & 570 & 37.5 \\
\hline 21 & Kingbird & 307.5 & 18.98 & 2060 & 55.83 & 1045 & 68.75 \\
\hline 22 & Wane & 162 & 10 & 1710 & 46.34 & 475 & 31.25 \\
\hline 23 & DAKA & 335 & 20.68 & 1230 & 33.33 & 570 & 37.5 \\
\hline 24 & Balcha & 112 & 6.9 & 280 & 7.5 & 140 & 9.2 \\
\hline 25 & Morocco Sus. Ch & 1620 & 100 & 3690 & 100 & 1520 & 100 \\
\hline
\end{tabular}

AUDPC, area under disease progress curve, rAUDPC relative area under disease progress curve.

\subsection{Area Under Disease Curve and Relative Area Disease Progress Curve}

Selecting of cultivars with having terminal rust severity less than $30 \%$ and coefficient of infection between 0 to 20 are acceptable partial slow rusting in field experiments for practical purpose. The cultivars having rAUDPC values up to $40 \%$ of check Morocco were grouped as high level of partial 
resistance consisted of six wheat cultivars includes Sanate, Balcha, Dashen, Madawalabu, DAKA and Pavon 76; while those having rAUDPC values up to $70 \%$ of check were grouped as moderately resistant to moderately susceptible cultivars, includes Galama, Hogana, Alidoro, Wane, shorima, Kingbird, Danada, Huluka, Hidasie and Lemmu. Of the wheat cultivars having the rAUDPC values between 70 to $100 \%$ of check cultivar were grouped as low level of partial resistance includes, Kakaba, PBW 343, Enkoy, Ogolcho, Digalu, Kubsa, Isreal, Lakech and Morocco showed $\mathrm{S}$ disease reaction and known as susceptible cultivars over all location. Generally, thrity six percent of the tested materials were grouped as low adult plant resistance and susceptible cultivars that needs effective fungicides with determined spraying frequencies.

According to [29-34] the cultivars with having low terminal rust severities along with coefficient of infection and field selection of slow rusting traits with low rAUDPC preferably feasible where greenhouse facilities are in adequate and experimental stations are hotspot throughout the season. These wheat cultivars initially displayed rust infection and sporulation but the last host reaction was described as chlorotic and necrotic lesions. Consequently, the disease progression continued slower and highly delayed among these cultivars. Such partly resistant cultivars could highly delay evolution of new virulent races of the pathogen because multiple point mutations are very rare in normal [35-37]. Similarly, regardless of the MS infection type displayed on moderately slow rusting cultivars yellow rust established incorrectly as shown by their AUDPC values. None of the tested cultivars were manifested as having resistant field response while $85 \%$ of the tested cultivars were clustered as susceptible having $\mathrm{S}$ type of field response during the 2020 cropping season. The high and moderate adult plant resistant wheat cultivars recognized in the present study were suggested to be having genes for different degrees of slow rusting and may be used for extra genetic manipulation in wheat development program.

Table 5. Stripe rust AUDPC and rAUDPC values of commercial cultivars at Kulumsa, Meraro and Bekoji in 2020 cropping season.

\begin{tabular}{|c|c|c|c|c|c|c|c|}
\hline \multirow{2}{*}{ S/NO } & \multirow{2}{*}{ Cultivars } & \multicolumn{2}{|l|}{ Kulumsa } & \multicolumn{2}{|l|}{ Meraro } & \multicolumn{2}{|l|}{ Bekoji } \\
\hline & & AUDPC & rAUDPC & AUDPC & rAUDPC & AUDPC & Raudpc \\
\hline 1 & Digalu & 1400 & 64.52 & 2380 & 100 & 1540 & 81.48 \\
\hline 2 & Kubsa & 1750 & 80.65 & 2310 & 97.06 & 1750 & 92.59 \\
\hline 3 & PBW343 & 1470 & 67.74 & 2170 & 91.18 & 1540 & 81.48 \\
\hline 4 & Dashen & 1260 & 58.06 & 1295 & 54.41 & 385 & 20.37 \\
\hline 5 & Lakech & 1610 & 74.19 & 1890 & 79.41 & 1540 & 81.48 \\
\hline 6 & Sanate & 875 & 40.32 & 1400 & 58.82 & 1225 & 64.81 \\
\hline 7 & Isreal & 1400 & 64.52 & 1680 & 70.59 & 1820 & 96.3 \\
\hline 8 & Enkoy & 665 & 30.64 & 1400 & 58.82 & 1190 & 62.96 \\
\hline 9 & Pavon 76 & 805 & 37.1 & 1295 & 54.41 & 945 & 50 \\
\hline 10 & Shorima & 1120 & 51.61 & 1225 & 51.47 & 875 & 46.3 \\
\hline 11 & Galama & 910 & 41.94 & 1890 & 79.41 & 1260 & 66.67 \\
\hline 12 & Kakaba & 1120 & 51.61 & 2205 & 92.65 & 1190 & 62.97 \\
\hline 13 & Ogolcho & 1750 & 80.65 & 1960 & 82.35 & 1820 & 96.3 \\
\hline 14 & Danda'a & 560 & 25.81 & 1120 & 47.06 & 805 & 42.59 \\
\hline 15 & Lemmu & 840 & 38.71 & 2030 & 85.29 & 525 & 27.78 \\
\hline 16 & Alidoro & 525 & 24.19 & 1225 & 51.47 & 700 & 37.04 \\
\hline 17 & Huluka & 1190 & 54.83 & 1365 & 57.35 & 1750 & 92.59 \\
\hline 18 & Hogana & 840 & 38.71 & 1085 & 45.59 & 1470 & 77.78 \\
\hline 19 & Madawalabu & 1505 & 69.36 & 1365 & 57.35 & 1400 & 74.07 \\
\hline 20 & Hidasie & 1155 & 53.23 & 1505 & 63.24 & 1120 & 59.26 \\
\hline 21 & Kingbird & 770 & 35.48 & 1960 & 82.35 & 1225 & 64.81 \\
\hline 22 & Wane & 525 & 24.19 & 1190 & 50 & 560 & 29.63 \\
\hline 23 & DAKA & 175 & 8.06 & 735 & 30.88 & 630 & 33.33 \\
\hline 24 & Balcha & 168 & 7.74 & 490 & 20.59 & 385 & 20.37 \\
\hline 25 & Morocco Sus. ch & 2170 & 100 & 2380 & 100 & 1890 & 100 \\
\hline
\end{tabular}

AUDPC, area under disease progress curve, rAUDPC relative area under disease progress curve.

\section{Conclusion}

Most of the evaluated cultivars exhibited low slow rusting performance under high disease pressure shown by susceptible check morocco. Wheat cultivar only Balcha showed lesser levels of FRS $(<30 \%$ with MR and MS responses) and coefficient of infection $(<20)$ signifying a high level of slow rusting resistance over all location. Currently in Ethiopia especially Arsi and West Arsi wheat producing areas are hotspots to the yellow rust epidemics and hence there is a change in races and possibility of happening new races due to lack of varietal deployment law and a change in environment throughout the year. Therefore development of slow rusting resistant varieties and identifying genes with horizontal resistance across with different regions is important to combat the epidemics and reduce yield loss caused by yellow rust. In Ethiopia, $88 \%$ of the cultivated cultivars were highly susceptible to wheat yellow rust that cannot be produced without frequent application of fungicides. So wheat producers including formers, Government run and private wheat fields should be supported by effective fungicides to manage its pressure and reduce yield loss caused by yellow rust. 


\section{References}

[1] Chai Y., Kriticos D. J., Beddow J. M., Duveiller E., Cuddy W., Yonow T. \& Sutherst R. W., 2015. Puccinia striiformis. Harvest Choice Pest Geography. St. Paul, MN: InSTePPHarvest Choice. 27-332-355.

[2] Aquino P., Carrion F. \& Calvo R., 2002. Selected wheat statistics. In: World Wheat Overview and Outlook 2002-2001: Developing No-Till Packages for Small-Scale Farmers. (Journal of Ekboir, ed.). CIMMYT, Mexico DF. 52-62.

[3] Singh RP., William HM., Huerta-Espino J. \& Rosewarne G., 2004. International surveillance of wheat rust pathogens: Progress and challenges, specific areas of the country with new technologies including wheat varieties. Proceedings 4th International Crop Science Congruence.

[4] Chen X. M., 2005. Epidemiology \& control of stripe rust (Puccinia striiformis f. sp. tritici) on wheat. Canadian Journal of Plant Pathology. 27: 314-337.

[5] Ayele Badebo, Fehrmann H. \& Yahyaoui A. 2008a. Status of wheat stripe rust (Puccinia striiformis) races and their virulence in major wheat growing areas of Ethiopia. Pest Management Journal of Ethiopia. 12: 1-7.

[6] Worku Denbel, 2014. Epidemics of Puccinia striiformis f. sp. tritici in Arsi and West Arsi Zones of Ethiopia in 2010 and identification of effective resistance genes. Journal of Natural Science Research. 4: 33-39.

[7] Ayele Badebo. 2002. Breeding bread wheat with multiple disease resistance and high yield for the Ethiopian highlands: Broadening the genetic basis of yellow rust and tan spot resistance. PhD Thesis. Cuvillier Verlag Goettingen, Germany. Pp. 115.

[8] Alemu Ayele \& Getnet Muche, 2019. Yield Loss Assessment in Bread Wheat Varieties Caused by Yellow Rust (Puccinia striiformis f. sp. tritici) in Arsi Highlands of South Eastern Ethiopia. American Journal of BioScience. Vol. 7, No. 6, pp. 104-112. doi: 10.11648/j.ajbio.20190706.14.

[9] Kumar K., Holtz M. D., Xi K. \& Turkington T. K. 2012. Virulence of Puccinia striiformis on wheat and barley in central Alberta. Canadian Journal of Plant Pathology. 34: 4, 551- 561.

[10] Bolton CD, Kolmer JA, Garvin DF (2008). Pathogen profile: Wheat leaf rust caused by Puccinia triticina. Mol. Plant Pathol. 9: 563-575.

[11] Draz IS, Abou-Elseoud MS, Kamara AM, Alaa-Eldein OA, ElBebany AF (2015). Screening of wheat genotypes for leaf rust resistance along with grain yield. Ann. Agric. Sci. 60: 29-39.

[12] Sawhney RN (1995). Genetics of wheat-rust interaction. In. J. Janick. (ed.) Plant Breeding Reviews 13. John Wiley and Sons. Inc. USA.

[13] Priyamvada, M., S, S., Tiwari, R. 2011. Durable resistance in wheat. International Journal of Genetics and Molecular Biology Vol. 38, pp. 108-114.

[14] Parlevliet, J. E. 1985. Resistance of the Non-Race-Specific Type. pp 485-507 In: A. P. Roelfs \& W. R. Bushnell (Eds.) 'The Cereal Rusts, Vol II'. Academic Press, London.

[15] McIntosh, R. A., Wellings C. R., Park R. F. 1995 Wheat rusts: an atlas of resistance genes. CSIRO Publishing, Melbourne.
[16] Herrera-Foessel SA, Singh RP, Huerta-Espino J, Crossa J, Djurle AJ, Yuen J (2007). Evaluation of slow rusting resistance components to leaf rust in CIMMYT durum wheats. Euphytica 155: 361-369.

[17] Parlevliet, J. E., Van-Ommeren, A. 1975. Partial resistance of barley to leaf rust, Puccinia hordei. II. Relationship between field trials, micro plot tests and latent period. Euphytica 24, 293-303.

[18] Paterson, R. F., Campbell, A. B. and Hannah, A. E. 1948. A diagrammatic scale for estimating rust intensity on leaves and stems of cereals. Canadian Journal of Research, 26: 496-500.

[19] Roelfs, A. P., Singh, R. P. and Saari, E. E. 1992. Rust Diseases of Wheat: Concepts and Methods of Disease Management. Mexico, DF: CIMMYT.

[20] Saari EE, Wilcoxson RD (1974). Plant disease situation of high yielding durum wheat in Asia and Africa. Annu. Rev. Phytopathol. 2: 49-68.

[21] Arama P. F., Parlevliet J. E. \& Van Silfhout C. H. 2000. Heading date and resistance to septoria tritici blotch in wheat not genetically associated. Journal of Euphytica. 106: pp. 63-68.

[22] Milus, E. A. and Line, R. F. 1986. Gene action for inheritance of durable, high temperature, adult plant resistance to stripe rust in wheat. Phytopathology, 76: 435-441.

[23] Nzuve FM, Bhavani S, Tusiime G, Njau P, Wanyera R (2012). Evaluation of bread wheat for both seedling and adult plant resistance to stem rust. Afr. J. Plant Sci. 6: 426-432.

[24] Ali S, Jawad S, Shah A, Ibrahim M (2007). Assessment of wheat breeding lines for slow yellow rusting (Puccinia striformis west. tritici). Pak. J. Biol. Sci. 10: 3440-3444.

[25] Li ZF, Xia XC, He ZH, Li X, Zhang LJ, Wang HY, Meng QF, Yang WX, LiG Q, Liu DQ (2010). Seedling and slow rusting resistance to leaf rust in Chinese wheat cultivars. Plant Dis. 94: 45-53.

[26] Tabassum S (2011). Evaluation of advance wheat lines for slow yellow rusting (Puccinia striiformis f. sp. tritici). J. Agric. Sci. 3: 239-249.

[27] Safavi SA (2012). Evaluation of slow rusting parameters in thirty seven promising wheat lines to yellow rust. Tech. J. Eng. Appl. Sci. 2: 324- 329.

[28] Parlevliet, J. E. 1988. Resistance of the Non-Race-Specific Type. In "The Cereal Rusts", Vol. II. Diseases, Distribution, Epidemiology and Control, Academic Press, Orelando.

[29] Brown WMJ, Hill JP, Velasco VR (2001). Barley yellow rust in North America. Annu. Rev. Phytopathol. 39: 367-384.

[30] Singh RP, Huerta-Espino J, William HM, 2005. Genetics and breeding for durable resistance to leaf and stripe rusts in wheat. Turk. J. Agric. For. 29: 121-127.

[31] Singh D, Park RF, McIntosh RA (2007). Characterization of wheat leaf rust resistance gene Lr34 in Australian wheats using components of resistance and the molecular marker csLV34. Aust. J. Agric. Res. 58: 1106-1114.

[32] Kaur J, Bariana HS (2010). Inheritance of adult plant stripe rust resistance in wheat cultivars Kukri and Sunco. J. Plant Pathol. 92: 391-394. 
[33] Safavi SA, Ahari AB, Afshari F, Arzanlou M (2013). Slow rusting resistance in Iranian barley cultivars to Puccinia striiformis f. sp. hordei. J. Plant Prot. Res. 53: 6-11.

[34] Hei N, Shimelsi H, Laing M, Admassu B (2014). Assessment of Ethiopian wheat lines for slow rusting resistance to stem rust of wheat caused by Puccinia graminis f.sp. tritici. J. Phytopathol. 163: 353-363.

[35] Schafer, J. F., Roelfs, A. P. 1985. Estimated relation between numbers of urediniospores of Puccinia graminis tritici and rates of occurrence of virulence. Phytopath 75, 749-750.

[36] Ali S, Shah SJA, Maqbool K (2008). Field-based assessment of partial resistance to yellow rust in wheat germplasm. J. Agric. Rural Dev. 6: 99-106.

[37] Tsilo TJ, Jin Y, Anderson JA (2010). Identification of Flanking Markers for the Stem Rust Resistance Gene Sr6 in Wheat. Crop Sci. 50: 1967- 1970. 